\title{
Lincosamide Antibiotic
}

National Cancer Institute

\section{Source}

National Cancer Institute. Lincosamide Antibiotic. NCI Thesaurus. Code C82922.

Any synthetic or semi-synthetic derivative of lincomycin, first isolated from a soil actinomycete Streptomyces lincolnensis, with antibacterial activity. Lincosamide antibiotics bind to the $23 \mathrm{~S}$ rRNA in the large 50S subunit of bacterial ribosomes, thereby preventing the peptidyl-tRNA translocation from the $\mathrm{A}$ site to the $\mathrm{P}$ site. This results in peptidyl-tRNA dissociation from ribosomes, and leads to the release of incomplete proteins, ultimately causing cell death. 